\title{
PERCENTAGE OF SELF-FEEDING PRACTICE IN BABIES USING BABY-LED AND TRADITIONAL WEANING IN INDONESIA
}

\author{
Dian Susmarini1 ${ }^{1}$, Atyanti Isworo ${ }^{2}$, Made Sumarwati ${ }^{3}$, Lutfatul Latifah ${ }^{4}$ \\ 1. Pediatric Nursing Lab, Jenderal Soedirman University \\ 2. Medical Surgical Nursing Lab, Jenderal Soedirman University \\ 3. Fundamental Nursing Lab, Jenderal Soedirman University \\ 4. Maternity Nursing Lab, Jenderal Soedirman University
}

\begin{abstract}
Baby-led weaning is a new method of complementary food introduction for babies which enables babies to feed themselves. Over the last decade, the number of mothers adopting this method has been growing in many countries including Indonesia, though the exact number is unknown. The practice of self-feeding in babies using baby-led weaning in Indonesia also has not been identified. The aim of this study was to identify self-feeding practices among babies in both baby-led and traditional weaning. The study design was that of a descriptive survey given to a population of the mothers of six to 12-month-old babies who practiced either baby-led or traditional weaning in Indonesia. A consecutive sampling technique with time limit was used, and 316 respondents were recruited through an online survey. Respondents completed a set of questionnaire consisting of mother and baby data characteristics and a self-reported of self-feeding practice. A univariate analysis was used to explain the data. The results showed almost half of the baby-led weaning group practiced self-feeding at least $90 \%$ of their meals, whereas $80 \%$ of the traditional weaning babies practiced spoon-feeding at least $90 \%$ of their meals. The self-feeding percentage in the rest of the baby-led weaning participants, however, ranged from 10 to $75 \%$. The type of family, who is appointed to take care of the baby, mother's occupation, and engagement in family dining may contribute to the variations in self-feeding percentages. In conclusion, self-feeding practice was higher in baby-led weaning group compared to that in traditional weaning group, as assumed. The unique percentage of self-feeding practice among baby-led weaning in Indonesia is useful as a reference for further research in this area and as a comparison with the practice in other countries.
\end{abstract}

Key words: baby-led weaning, feeding practice, traditional weaning

\section{ABSTRAK}

Baby-led weaning adalah metode baru memperkenalkan makanan tambahan dengan ciri bayi memasukkan sendiri makanan ke mulutnya. Selama dekade terakhir, jumlah ibu yang menggunakan metode ini meningkat di beberapa negara termasuk di Indonesia. Namun hingga kini praktik metode baby-led weaning di Indonesia belum diteliti. Penelitian ini bertujan mengidentifikasi pola bayi makan sendiri pada bayi baby-led weaning dan metode tradisional. Desain penelitian ini adalah deskriptif dengan populasi bayi berusia 6-12 bulan baik yang menggunakan baby-led weaning ataupun metode tradisional. Pengambilan sampel dengan teknik konsekutif dengan batasan satu bulan, dan 316 responden didapatkan melalui survey online. Hampir setengah dari bayi yang menggunakan baby-led weaning makan sendiri pada $90 \%$ jadwal makannya, sementara $80 \%$ bayi dengan metode tradisional disuapi. Praktik makan sendiri pada setengah kelompok baby-led weaning lainnya bervariasi dari 10 hingga $75 \%$ dari seluruh jadwal makannya. Tipe keluarga, orang yang ditunjuk sebagai pengasuh bayi, pekerjaan ibu, keterlibatan bayi pada makan bersama keluarga dapat berhubungan dengan variasi prosentase praktik makan sendiri pada bayi. Dari penelitian ini dapat dilihat terdapat perbedaan pola makan pada bayi dengan baby-led weaning dan metode tradisional. Prosentase yang unik pada babyled weaning di Indonesia berguna sebagai bahan kajian bagi penelitian mendatang pada area ini.

Kata kunci: baby-led-weanig, pola makan, metode tradisional 


\section{BACKGROUND}

The number of mothers practicing baby-led weaning as a new method to introduce complementary food among babies has been growing in many countries. This method is considered new since it has gained popularity (Brown \& Lee, 2013)(Arden \& Abbott, 2015) in the last decade (Brown, Jones, \& Rowan, 2017). To date, studies in this field have only been conducted in a few countries such as the UK, New Zealand (Arden \& Abbott, 2015) and Canada (D'Andrea, Jenkins, Mathews, \& Roebothan, 2016) which suggests that more explorations are required.

The introduction of complementary food to babies has traditionally involved spoon-feeding babies. A mother would prepare a meal and feed the baby, controlling how much the baby ate, following a determined daily meal schedule and controlling the pace the baby ate (Rapley, 2011). With babyled weaning, the control is given to the babies (Arden \& Abbott, 2015).

The growing popularity of babyled weaning is seemingly related to the recognized benefits of this method. Benefits include more developed oral skills and skill development (Brown et al., 2017)(Brown \& Lee, 2013)(Daniels et al., 2015), babies becoming less picky in eating habits and gaining the ability to determine the amount of food they eat (Rapley, 2011). Additionally, baby-led weaning has been found to reduce the risk of obesity later in life (Brown \& Michelle, 2011)(Daniels et al., 2015). Nonetheless, disadvantages of baby-led weaning have also been observed. These include irondeficient anaemia as a result of insufficient iron intake (D'Auria et al., 2018), underweight toddlers (Arden \& Abbott, 2015) and a higher risk of choking (Brown \& Michelle, 2011)(Daniels et al., 2015). Conversely, a recent study found that in modified baby-led weaning, zinc intake did not show any decrease (Daniels et al., 2018). A recent modification of baby-led weaning called Bliss (baby-led introduction to solids) promotes low-risk-choking foods and a variety of iron-rich foods (Daniels et al., 2015)(Cameron, Taylor, \& Heath, 2015). Studies of the effects of baby-led weaning in older babies are still being undertaken, and more random controlled trial studies are needed (Daniels et al., 2015).

Simultaneously to the increase in studies, baby-led weaning has gained in popularity among Indonesian mothers, as an alternative to traditional weaning which has been practiced for generations. Although the exact number of mothers practicing baby-led weaning is unknown, its growing popularity can be seen through the rise of baby-led weaning online communities on Facebook, online web discussions and Instagram. Several Instagram accounts were identified, with the biggest one having more than sixty thousand followers. This community is predicted to increase, which is indicated by more discussions appearing in social media.

Despite its growing popularity, however, there has been no research on baby-led weaning practice in Indonesia. There are many aspects to be examined including, but not limited to, the mother's decision to opt for this method, the practice and its effects in later age. Additionally, as a new method, challenges from culture and environment are inevitable. This initial study looked at the practice of baby-led weaning among Indonesian babies in order to obtain a clear understanding of its application.

The aim of this research was to describe the practice of self-feeding in baby-led weaning and traditional weaning in Indonesia. A detailed percentage was needed to illustrate the variety of feeding portions in both groups.

\section{METHODS}

A descriptive design illustrated the self-feeding versus spoon-feeding portions in the baby-led weaning and traditional weaning groups. This was the appropriate method to answer the aim of this research. Self-feeding describes the process where baby feed himself with spoon or hand, and independently determines how much he eats. Traditional weaning babies are fed a prescribed amount of food by their caregivers. The measurement of feeding portions in this research was based on self-rated 
assessments. Prior to the study, an approval from the Ethical Committee of Medicine faculty at Jenderal Soedirman University (Registration number: 192/KEPK/VI/2018) was gained. This research was conducted from June to September 2018. An online informed consent was obtained through a survey website before the data collection by asking participant to write the name and click the agree button.

\section{Participants}

Participants were mothers and babies aged six to 12 months who were recruited using a consecutive sampling technique. The online survey was delivered via Survey Monkey with announcements put out on an online mothers' community and the biggest Instagram page for the baby-led weaning mother's community in Indonesia. Bias that may be caused by fake respondent was minimized by respondent recruitment through trusted platforms which have loyal and open communication among members. The online survey was used for both groups in order to eliminate the limitations of a previous study conducted by another researcher, which recruited baby-led weaning participants from an online survey and traditional weaning participants from the local community (Brown \& Lee, 2013). Over one month, as many as 316 mothers completed the selfreport questionnaire. Exclusion was made to Indonesian mothers living overseas, as it may create bias in terms of family support. These participants were then classified as either baby-led weaning (123) or traditional weaning (193) purely based on their self-report.

\section{Data analysis}

Univariate descriptive statistics were used to describe mothers' age, occupation, family type, family members involved in the care of babies, self-feeding and spoon-feeding proportions, and babies' eating behaviours. Chi square tests and Kolmogorov-Smirnov test were performed to determine the differences of these characteristics in both groups.

\section{RESULTS}

The research involved 316 participants, most of whom were aged between 25 and 34 years, with less than $6 \%$ of participants aged either below 18 or above 35 . There was no significant difference in participants' age.

Family types were divided into two: nuclear or extended family. In the traditional weaning group, extended family was dominant, while in the baby-led weaning group, both types were equal. Babies' engagement in family dining was also explored to gain more understanding about family eating behaviours. It was revealed that babies in the baby-led weaning group were more often involved in family dining. Statistically, there was a difference in occupation, family type, babies cared for by other people, and babies' engagement in family dining between the baby-led weaning and traditional weaning groups. More detailed characteristics are described in table 1.

The involvement of person other than parents who helped caring for the babies was seen higher in the traditional weaning group. Table 2 describes the person who helped parents to care for the babies. Maternal grandmother was the most common caregiver, and nanny ranked the second. Five respondents reported neighbour as the caregiver. Between the groups, there was no significant difference in persons appointed to care for the baby.

The main aim of this research was to examine the differences in feeding practices between self-defined baby-led weaning mothers and self-defined traditional weaning mothers. It is interesting that both groups shared a common trend in a reverse direction. More than $43 \%$ of the baby-led weaning participants practiced self-feeding for the majority of their meals (at least 90\%), while nearly half of traditionally weaning babies were $100 \%$ spoon fed. However, one participant whose baby self-fed $90 \%$ of the time defined herself as following baby-led weaning practices. 
Table 1. Demographic characteristics

\begin{tabular}{|c|c|c|c|}
\hline Variable & $\begin{array}{l}\text { Baby-led weaning } \\
(n=123)\end{array}$ & $\begin{array}{l}\text { Traditional weaning } \\
(n=193)\end{array}$ & $p$ value \\
\hline Age (years) & & & 0.541 \\
\hline Less than 18 & $3(2.4 \%)$ & $4(2.1 \%)$ & \\
\hline $18-24$ & $18(14.6 \%)$ & $41(21.2 \%)$ & \\
\hline $25-34$ & $95(77.2 \%)$ & $143(74.1 \%)$ & \\
\hline $35-44$ & $7(5.7 \%)$ & $5(2.6 \%)$ & \\
\hline Occupation & & & $0.000^{*}$ \\
\hline Housewife & $91(74 \%)$ & $110(57 \%)$ & \\
\hline Health professional & $5(4.1 \%)$ & $21(10.9 \%)$ & \\
\hline Labour & $16(13 \%)$ & $57(29.5 \%)$ & \\
\hline Self-employee & $11(8.9 \%)$ & $5(2.6 \%)$ & \\
\hline Family type & & & $0.001^{*}$ \\
\hline Nuclear & $61(49.6 \%)$ & $59(30.6 \%)$ & \\
\hline Extended & $62(50.4 \%)$ & $134(69.4 \%)$ & \\
\hline Baby cared by another person & & & $0.000^{*}$ \\
\hline Yes & $27(22 \%)$ & $85(44 \%)$ & \\
\hline No & $96(78 \%)$ & $108(56 \%)$ & \\
\hline $\begin{array}{l}\text { Babies' engagement in family } \\
\text { dining }\end{array}$ & & & $0.000^{*}$ \\
\hline Never & $7(5.7 \%)$ & $35(18.1 \%)$ & \\
\hline Rare & $37(30.1 \%)$ & $80(41.5 \%)$ & \\
\hline Often & 35 (28.5\%) & $45(23.3 \%)$ & \\
\hline Always & $44(35.8 \%)$ & $33(17.1 \%)$ & \\
\hline
\end{tabular}

Table 2. Persons involved in the care of baby

\begin{tabular}{lccc}
\hline $\begin{array}{c}\text { Assigned person to care for the } \\
\text { baby }\end{array}$ & $\begin{array}{c}\text { Baby-led weaning } \\
(\mathbf{n = 2 7 )}\end{array}$ & $\begin{array}{c}\text { Traditional weaning } \\
(\mathbf{n = 8 5})\end{array}$ & p value \\
\hline Maternal grandmother & $12(44.4 \%)$ & $42(49.4 \%)$ & 0.225 \\
Paternal grandmother & $4(14.8 \%)$ & $9(10.6 \%)$ & \\
Nanny & $7(25.9 \%)$ & $24(28.2 \%)$ & \\
Other family member & $3(11.1 \%)$ & $6(7.1 \%)$ & \\
Neighbour & $1(3.7 \%)$ & $4(4.7 \%)$ & \\
\hline
\end{tabular}

Table 3. Self-feeding percentage

\begin{tabular}{lccc}
\hline \multicolumn{1}{c}{ Self-feeding } & $\begin{array}{c}\text { Baby-led weaning } \\
(\mathbf{n = 1 2 3 )}\end{array}$ & $\begin{array}{c}\text { Traditional weaning } \\
(\mathbf{n}=\mathbf{1 9 3})\end{array}$ & p value \\
\hline $100 \%$ self-feeding & $22(17.9 \%)$ & $0(0 \%)$ & $0.000^{*}$ \\
$90 \%$ self-feeding & $32(26 \%)$ & $1(0.5 \%)$ & \\
$75 \%$ self-feeding & $24(19.5 \%)$ & $3(1.6 \%)$ & \\
$50 \%$ self-feeding & $22(17.9 \%)$ & $11(5.7 \%)$ & \\
$25 \%$ self-feeding & $17(13.8 \%)$ & $25(13 \%)$ & \\
$10 \%$ self-feeding & $6(4.9 \%)$ & $57(29.5 \%)$ & \\
$0 \%$ self-feeding & $0(0 \%)$ & $96(49.7 \%)$ & \\
\hline
\end{tabular}

\section{DISCUSSION}

The definitions of baby-led weaning and traditional weaning were stated at the beginning of the questionnaire with the aim of giving a clear explanation of the methods participants used with their babies. This prevented participants from guessing what kind of weaning they were practicing. The results of this research are slightly below the percentages of the existing findings from studies conducted in few other countries where the percentage of self-feeding practice ranged from 70 to $100 \%$.

Most self-defined baby-led weaning mothers $(81.3 \%)$ practiced selffeeding ranged from 50 to $100 \%$ of their meal, while most traditional weaning mothers (92.2\%) fed their babies ranging from 75 to $100 \%$ respectively. No selfdefined baby-led weaning mothers performed $100 \%$ spoon feeding, and no self-defined traditional weaning mothers performed $100 \%$ self-feeding. This 
indicates that participants understood the difference between the types of weaning. It also eliminated the possibility of participants wrongly chose the type of weaning they practiced.

In general, there was a significant difference in the feeding portion in both groups and the trend in the baby-led weaning group showed an opposite direction to that in the traditional weaning group, as have been assumed. However, the percentage of mothers who defined themselves as practicing baby-led weaning did not match Brown's definition. In her research, Brown and Michelle (2011) defines baby-led weaning as being $90 \%$ self-feeding with up to $10 \%$ traditional feeding in situations such as vacations or while traveling. In her later study, Brown (2016) took a wider view of baby-led weaning practices.

According to Cameron, Taylor and Heath (2015), the less than $10 \%$ selffeeding rule was not followed by all parents practicing baby-led weaning. As shown in table $3,43 \%$ of baby-led weaning participants were categorized as self-feeding more than $90 \%$ of the meal time, which is close to the definition of baby-led weaning. This figure was also seen in the traditional weaning group in which $20.8 \%$ participants practiced selffeeding more than $25 \%$ of the time. Twenty-two baby-led weaning mothers and 11 traditional weaning mothers practiced spoon feeding $50 \%$ of the time, meaning that, for many baby-led weaning mothers, allowing their babies to practice self-feeding sometimes is an effort to adopt to a new method. In traditional weaning, a $50 \%$ practice of self-feeding could be regarded as a way to prepare babies to feed themselves at a later age. Family type and the person looking after the babies are considered as contributing factors that made the percentage of mothers describing themselves as practicing baby-led weaning practice differently to the usual rules of baby-led weaning.

In Indonesia, most families practice traditional weaning, as their families have done for generations. Based on a study in Central Java Province conducted by Suwarsih and Zubaidah
(2016), it was found that people respect and fully obey the norms and culture regarding nurturing children. Nearly $50 \%$ of the baby-led weaning participants were nuclear families where more independency is allowed for mothers to apply a new method.

A more independent decision making to follow this new method may also be seen by the fact that participant recruitment for this research was through an online survey which implied that participants had access to the internet. A study about young mother's cultural beliefs in Indonesia revealed that easier internet access significantly changes young mothers' beliefs regarding breastfeeding practice (Anggraeni, Aji, Setiyani, Kartikasari, \& Rahmawati, 2018).

The other $50 \%$ of baby-led weaning participants lived with other members of the family, including maternal grandmother, paternal grandmother, aunt and other family members as well as a nanny. Those living in an extended family were likely to get supports from other family members in caring for the baby. Commonly, new mothers got help from their mother or mother-in-law, and were accompanied until their babies reached a certain age or when mothers were considered capable to manage and care for the baby themselves (Simbolon, 2009). This research found that of 122 mothers had the support of another person in the caring of their baby, more than half were supported by the baby's maternal grandmother who commonly practiced traditional weaning. When the babies' mothers wanted to apply a new method, the practice did not go easily, as the family tended to interfere with it. In a qualitative study about mother and mother-in-law's behaviour towards early complimentary feeding introduction in Indonesia, it was revealed that the mother and mother-inlaw serve a major influence in the mother's decision making (Suharni, 2017). Their behaviour tends to be influenced by normative belief within the community which supports this practice, and the fact that it has been practiced for generations. Findings from this excellent research could be the answer to why baby-led weaning 
practice in extended families faces more challenges.

Furthermore, working mothers often let the baby be cared for by another person at home or in childcare facility. Although only $26 \%$ of the baby-led weaning mothers worked on a daily basis, this number was viewed as the reason the self-feeding percentage was lower than expected. As stated previously, the fact that another person was in charge of caring for the baby became the assumed reason. The nanny, baby's grandmother or other family member caring for the baby may have a different style of feeding. A noteworthy finding was that a neighbour was hired to look after one baby and the baby was usually taken to the neighbour's house. The neighbour's main task was simply to make sure the baby was fine and calm while she was doing her house tasks. A control may be lacking in this case regarding how the neighbour fed the baby, thus making inconsistent self-feeding a possibility.

The frequency of babies' engagement in family dining could also contribute to more spoon feeding in the baby-led weaning group. Despite the fact that baby-led weaning babies naturally joined in with family dining, all members of the family should be informed regarding the mess the baby likely makes and extra time the baby take to eat. As shown in the results, almost all baby-led weaning babies joined the family at meal times, determined by the fact that the 'always join' option scored the highest (35\%). This number was a good indication of family participation in baby-led weaning. Only $17 \%$ of the traditional weaning babies reported "always join" in family dining. This finding contradicts with a Canadian study which finds that there was no evidence of more baby-led weaning babies dining with their families compared to traditional weaning babies (D'Andrea et al., 2016). Babies more frequently joining in family meals may mean more chance for spoon feeding, as the babies may be required to finish at the same time as everyone else does. This includes dining out where baby would eat at a different situation. Brown and Michelle (2011) stated that dining out is an excuse for spoon feeding.
The emphasis is on the difference between the actual self-feeding portion and what mothers perceived about the method they were following. To date, there has been no definition of the portion of self-fed babies defined as practicing babyled weaning (Brown et al., 2017). It is necessary to define what percentage of self-feeding baby-led weaning should be in order to know the boundaries and the exact development being expected from this method. However, respecting what mothers perceive and their efforts to practice their chosen method is also important. Characteristics of society, family and behaviour varies from country to country, meaning mothers may face different challenges in applying the method. In Indonesian culture, a baby is considered to be a weak creature who needs full assistance in feeding, therefore the idea of the baby determining how much he eats and being able to self-feed is uncommon. A valuable study from Singapore highlighted feeding practice in babies and found that self-feeding commonly started at the age of nine months (Toh et al., 2016). Further research into the relationship between culture differences and feeding practices needs to be taken into order to shape the illustration of baby-led weaning practices in different countries. Mothers may not focus on what percentage of time they allow their babies to self-feed, but, rather on making their babies feel comfortable. Although baby-led weaning may not be practiced in the majority of the time, mothers may be aiming to practice it when possible. Therefore, even though the percentage of self-feeding is lower than expected, it can still be considered babyled weaning.

Limitations of the study included the population and questionnaire. All participants were recruited from an online survey, which means the research does not represent the entire community, but only mothers with internet access. Almost all respondents had a high level of education, representing the characteristic of internet users. The questionnaire did not explore how mothers should precisely report the feeding portions. Ways to measure the exact portion of self-feeding 
should have been explained at the beginning of the questionnaire.

In summary, this study gives a different perspective of baby-led weaning practice, and a different percentage of self-feeding versus spoon feeding. The way mothers perceived both baby-led weaning and traditional weaning in terms of portion of self-feeding varied, and was different to that in other countries. A different perception regarding self-feeding portion between both groups contributes to the baby-led weaning literature on how mothers perceive their feeding practice. A recommendation for further research would be an investigation of feeding practices in various cultures to explain baby-led weaning practices in different countries.

\section{ACKNOWLEDGMENTS}

An appreciation to all participants from the Female Daily community and Ceritablw members.

\section{AUTHOR CONTRIBUTIONS}

DS designed and prepared the manuscript. Al and LL made correspondence with femaledaily and respondents and collected data. MS supported with the idea and assisted in writing the manuscript.

\section{FUNDING}

$\begin{array}{lrr} & \text { This research was supported by } \\ \text { annual } \quad \text { internal grant } & \text { (Kept. } \\ \text { 3715/UN23.14/PN.01.00/2018) } & \text { from } \\ \text { Jenderal Soedirman University. } & \end{array}$

\section{CONFLICT OF INTEREST}

No financial or nonfinancial benefits have been received or will be received from any party related directly or indirectly to the subject of this article.

\section{REFERENCES}

Anggraeni, M. D., Aji, B., Setiyani, R., Kartikasari, A., \& Rahmawati, E. (2018). How do modern parents deal with cultural beliefs on breastfeeding? A qualitative study. British Journal of Midwifery, 26(9), 1-9.
Arden, M. A., \& Abbott, R. L. (2015). Experiences of baby-led weaning: Trust, control and renegotiation. Maternal and Child Nutrition, 11(4), 829-844. https://doi.org/10.1111/ mcn.12106

Brown, A. (2016). Differences in eating behaviour, well-being and personality between mothers following baby-led vs. traditional weaning styles. Maternal and Child Nutrition, 12(4), 826-837. https://doi. org/10.1111/mcn.12172

Brown, A., Jones, S. W., \& Rowan, H. (2017). Baby-Led Weaning: The Evidence to Date. Current Nutrition Reports, 6(2), 148-156. https://doi. org/10.1007/s13668-017-0201-2

Brown, A., \& Lee, M. (2013). An exploration of experiences of mothers following a baby-led weaning style: developmental readiness for complimentary foods. Maternal and Child Nutrition, 9(2). https://doi.org/http://dx.doi.org/10.11 11/j.1740-8709.2011.00360.x

Brown, A., \& Michelle, L. (2011). Maternal control of child feeding during the weaning period: Differences between mothers following baby-led or standard approach. Maternal Child Health Journal, 15, 12651271. https://doi.org/10.1007/s10995 -010-0678-4

Cameron, S. L., Taylor, R. W., \& Heath, A.-L. M. (2015). Development and pilot testing of Baby-Led Introduction to SolidS - a version of Baby-Led Weaning modified to address concerns about iron deficiency, growth faltering and choking. BMC Pediatrics, 15(1), 99. https://doi.org/10.1186/s12887-0150422-8

D'Andrea, E., Jenkins, K., Mathews, M., \& Roebothan, B. (2016). Baby-led Weaning: A Preliminary Investigation. Canadian Journal of Dietetic Practice and Research, 
77(2), 72-77. https://doi.org/10.3148 /cjdpr-2015-045

D'Auria, E., Bergamini, M., Staiano, A., Banderali, G., Pendezza, E., Penagini, F., ... Peroni, D. G. (2018). Baby-led weaning: What a systematic review of the literature adds on. Italian Journal of Pediatrics, 44(1), 1-11. https://doi.org/10.1186/s 13052-018-0487-8

Daniels, L., Heath, A.-L. M., Williams, S. M., Cameron, S. L., Fleming, E. A., Taylor, B. J., ... Taylor, R. W. (2015). Baby-Led Introduction to SolidS (BLISS) study: a randomised controlled trial of a baby-led approach to complementary feeding. BMC Pediatrics, 15(1), 179. https://doi.org/10.1186/s12887-0150491-8

Daniels, L., Taylor, R. W., Williams, S. M., Gibson, R. S., Samman, S., Wheeler, B. J., ... Heath, A.-L. M. (2018). Modified version of baby-led weaning does not lower zinc intake or infant status: A randomized controlled trial. Journal of the Academy of Nutrition and Dietetics. https://doi.org/http://dx.doi.org/10.10 16/j.jand.2018.02.005

Rapley, G. (2011). Baby-led weaning: transitioning to solid foods at the baby's own pace. Community Practitioner, 84(6), 20-23.

Simbolon, P. (2009). Family supports for mothers giving exclusive breast milk feeding in Pematang Siantar Indonesia. Indonesia University.

Suharni. (2017). Mother and mother in law's behavior in preventing exclusive breastfeeding practice in Jakarta. Universitas Islam Jakarta.

Suwarsih, N., \& Zubaidah. (2016). Obedience over culture and timing of initial complementary feeding in Kebumen. DIponegoro University. Retrieved from http://ejournals1.undip.ac.id/\%0A

Toh, J. Y., Yip, G., Han, W. M., Fok, D., Low, Y. L., Lee, Y. S., ... Chong, M. F. F. (2016). Infant feeding practices in a multi-ethnic Asian cohort: The GUSTO study. Nutrients, 8(5), 1-18. https://doi.org/10.3390/nu8050293 